\author{
Ahokas Jukka \& Hautala Mikko \\ Helsingin yliopisto, Maa- ja kotitalousteknologian laitos \\ Poikalainen Väino, Praks Jaan \& Veermäe Imbi \\ Viron maatalousyliopisto, Eläinlääketieteellinen tiedekunta, Tarto
}

\title{
Lehmän terveyden mittaaminen automaattilypsyn yhteydessä
}

\section{Johdanto}

Karjataloustöiden automatisointi ja tilakoon kasvu vieraannuttavat karjan hoitajastaan. Lehmien kuntoa ei enää pystytä tarkkailemaan samalla lailla kuin ennen, koska ne käyvät itsestään syömässä ja lypsyllä ilman, että ihminen seuraisi niiden toimintoja ja samalla niiden kuntoa. Tämä johtaa tilanteeseen, jossa lehmän alkava sairaus tai huono kunto voi kehittyä pahaksi ennen kuin se huomataan. Automaattilypsyn yhteydessä lehmät käyvät samalla asemalla kaksi - kolme kertaa vuorokaudessa. Käydessään ne joutuvat olemaan paikallaan pitkän ajan. Tätä voidaan käyttää hyväksi mittaamalla lypsyn aikana myös lehmän fysikaalista kuntoa. Tätä mahdollisuutta on tutkittu Euroopan aluekehitysrahaston rahoittamassa yhteistutkimuksessa, jossa mukana ovat Helsingin yliopistosta Maa- ja kotitalousteknologian laitos, Eläinlääketieteellinen tiedekunta, Suitian tutkimustila. Tutkimukseen osallistuvat myös Maa- ja elintarviketalouden tutkimuskeskuksen Maatalousteknologian tutkimus ja virolaisena osapuolena mukana on Viron maatalousyliopiston Eläinlääketieteellinen tiedekunta. Tutkimus alkoi vuonna 2003 ja se jatkuu vielä vuoden 2004. Vuoden 2003 aikana on tutkittu lehmän sorkkapainon mittaamismahdollisuutta ja siitä saatavan tiedon käyttöä.

\section{Aineisto ja menetelmät}

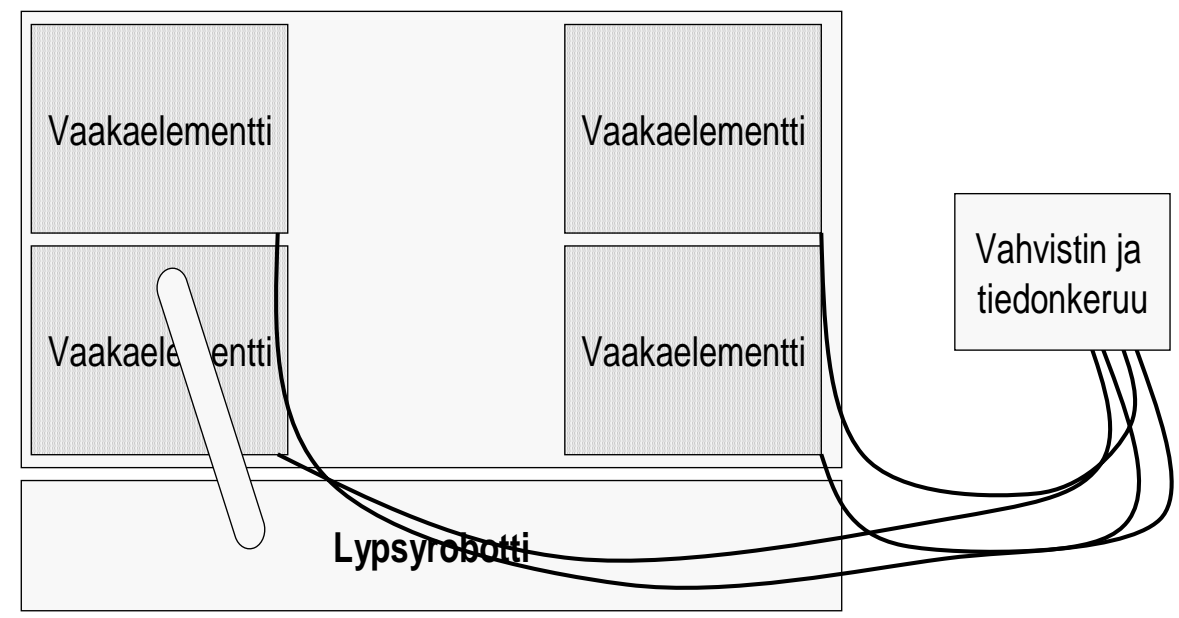

Kuva 1. Jalkapainojen mittausjärjestelmä

Mittausjärjestelmä koostuu lypsyrobotin yhteyteen rakennetusta punnituslavasta, jossa kunkin sorkan paino voidaan punnita erikseen lypsyn aikana. Mittauslaitteisto on esitetty kuvassa 1. Vaakaelementtien koko ja paikka määritettiin ennen laitteiston rakentamista Suitian tutkimustilan lehmien keskikokojen perusteella (Hämäläinen 2003). Karjasta yli 80 \% seisoo lypsettäessä kyseisten vaakalevyjen päälle. Suurimmat lehmät joutuvat seisomaan niin takana, että jalat eivät ole kokonaan levyjen päällä. Osa lehmistä pitää jalkojaan myös siten, että ne eivät aina ole punnituslevyjen päällä. 
Mittauslaitteiston muodostavat vaaka-anturit ja mittasiltavahvistin, joka on yhdistetty tietokoneeseen. Mittaus alkaa lehmän tullessa vaa’alle ja päättyy lehmän poistuessa vaa'alta. Laitteisto rekisteröi jalkojen painon mittauksen aikana jatkuvasti kaikilta jaloilta.
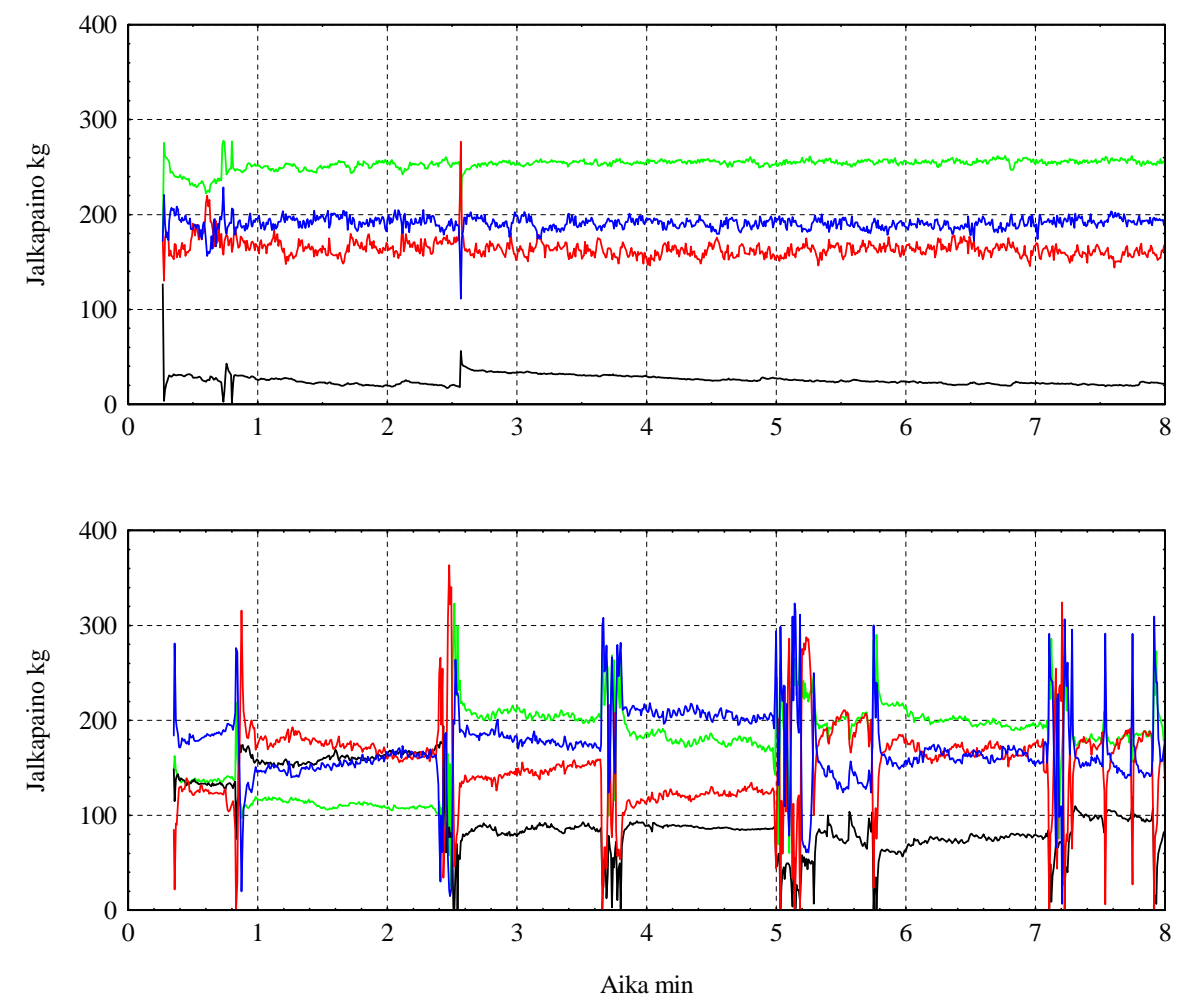

Kuva 2. Jalkapainojen mittaustulos lypsyn aikana

Kuvassa 2 on esimerkki rauhallisen (ylempi käyrästö) ja rauhattoman lehmän (alempi käyrästö) jalkapainoista lypsyn aikana. Käyrästön piikit kuvaavat jalkojen nostamista ja potkimisia lypsyn aikana. Ylemmässä kuvassa on nähtävissä vain pieniä jalkapainojen muutoksia. Siinä lehmän yksi jalka on myös ollut hieman vaakalevyn ulkopuolella ja sen takia yhden jalan painolukema on jäänyt hieman muita pienemmäksi. Alemman kuvan lehmä on potkinut useaan otteeseen lypsyn aikana. Potkiessa potkaisevalla jalalla oleva paino on nolla ja muille jaloille tämä paino tulee lisätukivoimina. Lisäksi eläimen huojunnoista aiheutuu myös tukivoimien muutoksia. 

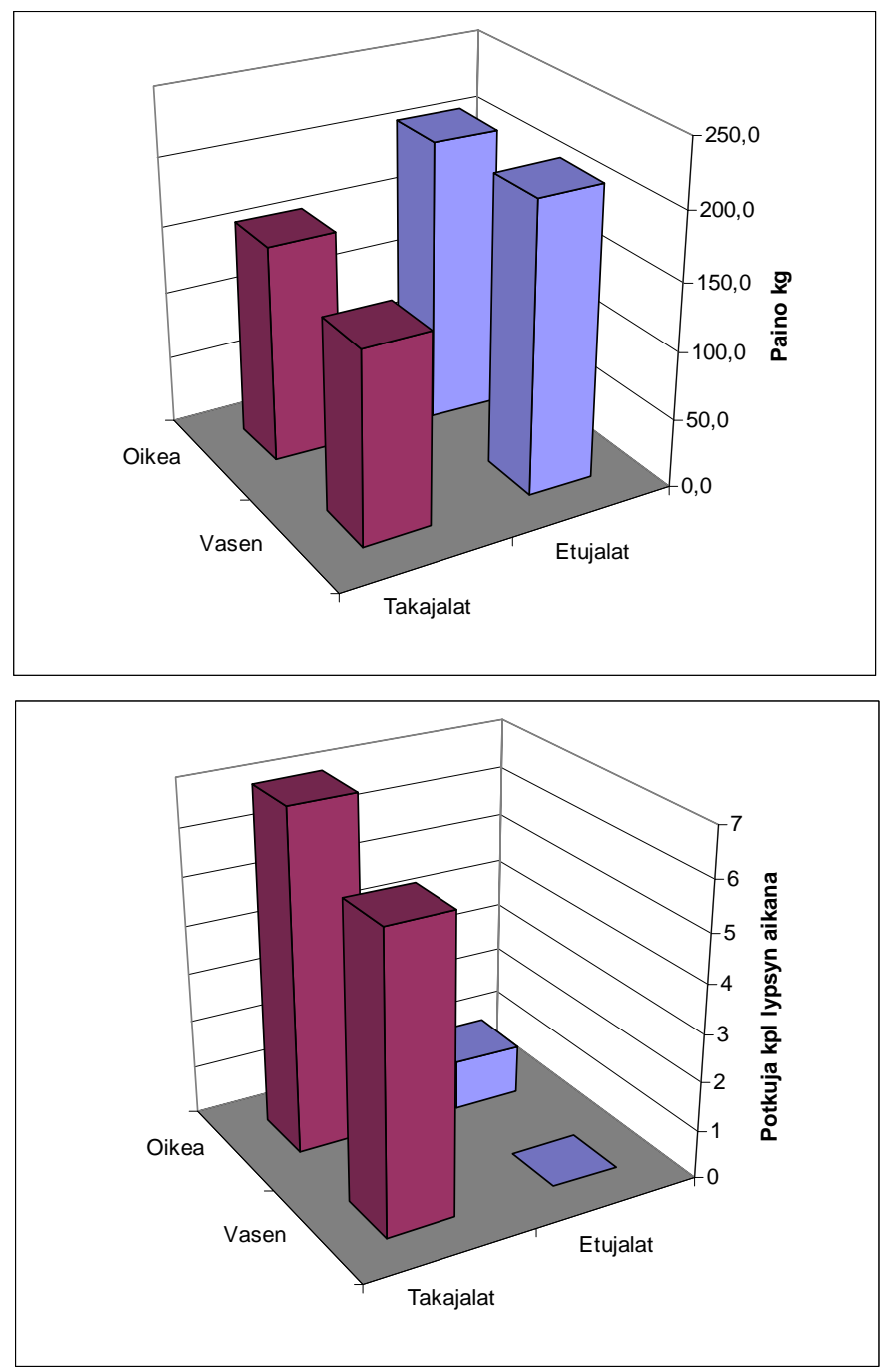

Kuva 3. Esimerkki lehmän painon jakaumasta ja potkuista lypsyn aikana

Kuvassa 3 on esitetty lehmän jalkapainot lypsyn aikana. Paino on selvästi etujalkojen päällä, noin 60 \% painosta on etujaloilla. Tämä on seurausta mm painavasta päästä, joka tukijalkojen ulkopuolella aiheuttaa painonsiirtoa takajaloilta etujaloille. Lypsyllä ollessaan lehmä potkii takajaloillaan. Etujaloilla potkiminen tai etujalkojen nostaminen on selvästi takajalkoja vähäisempää.

\section{Tulokset ja tulosten tarkastelu}

Laitteisto asennettiin lypsyrobotin asennuksen yhteydessä syksyn 2003 aikana. Sitä käytetään lehmien jalkapainoissa tapahtuvien muutosten seurantaan. Muutoksien avulla voidaan seurata lehmien sorkkaterveydessä ja käyttäytymisessä tapahtuvia muutoksia. Sorkkasairaudet ilmenevät jalkapainojen muutoksina, kipeälle jalalle ei tule yhtä paljon painoa kuin ennen. Tutkimuksessa kehitettyä laitteistoa tullaan käyttämään lypsyrobotin yhteydessä ja kerätystä tiedosta tullaan kehittämään lehmäkohtaisia terveys- ja käyttäytymisindeksilukuja. Laitteiston hinta on kohtuullinen verrattaessa sitä lypsyrobotin hintaan ja sen avulla voidaan saada tarpeellista ja automaattista tietoa lehmien terveydestä. 


\section{Johtopäätökset}

Laitteisto on suunniteltu ja asennettu käyttöönsä. Mittaustulokset osoittavat, että laitteiston avulla voidaan mitata lehmien jalkapainoja lypsyn yhteydessä. Tuloksia voidaan käyttää lehmien terveyden ja käyttäytymisen arviointeihin. Laitteiston toimiessa halutusti tutkimuksia jatketaan keräämällä tietoa ja analysoimalla niitä.

\section{Kirjallisuusluettelo:}

Hämäläinen Mika, Automaattisen sorkkakohtaisen painonmittausjärjestelmän punnitustasojen sijoitus. Kandidaatintutkielma, Helsingin yliopisto, Maa- ja kotitalousteknologian laitos, 2003. 